\title{
HIKAYAT RASULULLAH MENGAJAR FATIMAH: POSISIKAN WANITA DALAM PERAN YANG MULIA
}

\author{
oleh Haryadi \\ FBS Universitas Negeri Yogyakarta
}

\begin{abstract}
Feminism, in fighting for women's rights equal to men's, has at times developed into certain radicalism now and then going beyond and against what is natural between men and women. Such radicalism has given birth to an extremist feminine group trying to disassociate themselves from men by becoming lesbian feminists. If such a movement goes on uncontrolled, it will endanger human norms because the role of reproduction has then been denied. Hikayat Rasulullah Mengajar Fatimah, one of the treasured Indonesian literary works of old laden with positive values, can be among those that one is to reflect on in developing feminism more properly in Indonesia. Islamic in nature, it guides women to doing ten good acts and avoiding ten evils in the course of bringing forth a home replete with happiness. By means of the guidance women gain an exalted role in making a home heaven on earth The positive values in the literary work are reflected in exhortations to women, among others, (1) to do good as suggested by their spouse, (2) to be sweet of face and friendly in behavior, (3) to dress their spouse in good attire and scent, (4) to receive guests as requested by their spouse, (5) to ask their spouse for permission to do good, (6) to maintain goodness in their relation with their spouse, (7) to treat parents, siblings, teachers, and orphans with courtesy, and (8) to avoid being unfaithful to their spouse.
\end{abstract}

Key Words: feminism, Fatimah

\section{A.Pendahuluan}

Kualitas masyarakat sangat ditentukan oleh peranan manusia, baik pria maupun perempuan. Namun, dalam kenyataannya peran kaum wanita selalu terabaikan. Mereka hanya dianggap sebagai pelengkap dalam percaturan peradaban manusia. Bahkan, tidak jarang wanita dinilai sebagai pemuas nafsu belaka. Pemujaan terhadap kaum wanita 
umumnya lebih disebabkan oleh pertimbangan fisik dan biologis. Kondisi yang demikian itu berlangsung berada-abad lamanya sehingga dirasakan sebagai suatu penindasan terhadap kaum wanita.

Penindasan yang terjadi terhadap kaum wanita, mendorong lahirnya feminisme, yaitu suatu paham yang menuntut kesamaaan hak antara wanita dan pria. Feminisme telah menyebar ke seluruh dunia, termasuk Indonesia. Pada umumnya para feminis mempunyai pemahaman yang sama tentang ketidakadilan gender terhadap wanita, baik di dalam keluarga maupun masyarakat, namun mereka memiliki perbedaan pendapat tentang bentuk dan target yang ingin dicapai.

Di berbagai tempat protes terhadap ketidakadilan ini dirasakan telah berlebihan. Gerakan feminis radikal, misalnya, berusaha menghapus perbedaan jenis kelamin. Mereka berpendapat bahwa kelemahan wanita sebenarnya berakar pada struktur biologisnya, sehingga mereka harus merasakan sakit ketika melahirkan, mengasuh anak, menyusui, dan lain-lain. Oleh karena itu, mereka menuntut agar wanita diberi kesempatan untuk menentukan pilihan antara melahirkan sendiri, melahirkan buatan, atau tidak melahirkan sama sekali. Bahkan, kelompok yang sangat ekstrem dari gerakan ini berusaha memutuskan hubungan dengan laki-laki. Mereka berpendapat sepanjang wanita masih meneruskan hubungannya dengan pria, maka tidak mungkin bagi mereka untuk berjuang melawan lelaki (Wa Islama, 32/XII, 19 April 2002:3)

Perjuangan kaum feminis untuk menuntut persamaan hak telah bergeser pada tataran perlawanan, baik terhadap kaum pria maupun terhadap kondratnya sendiri. Apabila paham semacam itu dianut oleh sebagain besar kaum wanita dapat diramalkan bahwa perjuangan mereka akan gagal. Kaum wanita justru akan terpuruk oleh perjuangannya sendiri.

Akibat terputusnya hubungan pria dan wanita, angka kelahiran akan berkurang. Jumlah wanita mungkin menjadi lebih banyak dari kaum pria atau sebaliknya. Kondisi seperti itu tidak ubahnya buah 
simalakama, yang tidak menguntungkan sama sekali. Wanita dalam jumlah banyak akan mudah dilecehkan. Sebaliknya, wanita dalam jumlah yang sedikit akan menjadi ajang perebutan. Dalam kondisi yang serba tidak menguntungkan itu, kaum wanita akan mengalami penindasan yang tidak terperikan.

Lalu, ke mana feminisme akan diarahkan? Jawabannya berpulang pada kaum wanita. Namun, orang yang masih berhati nurani akan sependapat bahwa kaum wanita harus diposisikan pada peran yang mulia, yaitu menciptakan kesejahteraan dan kebahagiaan hidup, baik dalam lingkup mikro maupun makro. Di dalam rumah tangga, wanita berperan mewujudkan kebahagiaan. Sementara itu, dalam masyarakat yang lebih luas wanita berperan menciptakan kedamaian dan kesejahteraan. Dengan kata lain, wanita berperan mewujudkan surga.

Tuntunan untuk mendudukkan wanita dalam peran yang sangat mulia banyak ditemukan dalam sastra lama. Salah satunya adalah Hikayat Rasulullah Mengajar Fatimah. Hikayat ini disusun berdasarkan kaidah-kaidah islami. Meskipun demikian, tuntunan yang terdapat di dalamnya bersifat universal sehingga memungkinkan untuk diterapkan pada berbagai kelompok masyarakat.

Hikayat Rasulullah Mengajar Fatimah (selanjutnya disingkat $H R M F$ ) ini merupakan transformasi budaya yang timbul akibat masuknya Islam ke Indonesia. Islam yang berkembang di Indonesia telah memberikan kontribusi yang sangat berarti bagi pengembangan budaya dan sastra. Hal ini terlihat pada cara penyebaran, tema, dan jenis karya sastra. Tradisi lisan yang mendominasi berbagai kegiatan, semenjak masuknya Islam lambat-laun berubah menjadi tradisi tulis, dengan memanfaatkan huruf Arab untuk menuliskan bahasa Melayu.

Perubahan dari tradisi lisan ke tradisi tulis, meski baru dalam tahap tulisan tangan, telah memberikan andil yang cukup besar pada perkembangan naskah. Pendokumentasian tradisi lisan ke dalam bentuk tulis, atau penyalinan naskah berkembang dengan pesat. Hasilnya adalah berbagai naskah tulisan tangan. Dalam perkembangnnya naskah-naakah 
itu ada yang dibawa ke luar daerah, dan kini tersimpan di berbagai negara. Sutrisno (1981:12) menyebutkan ada sekitar 26 negara yang menyimpan naskah lama Indonesia, sementara Dipodjojo (1981: 5) memperkirakan tidak kurang dari 5000 naskah tersimpan di berbagai perpustakaan di luar negeri.

$H R M F$ merupakan salah satu naskah yang tersimpan di Musium Pusat Jakarta. Hikayat ini jarang dibicarakan oleh para ahli. Winsted dalam bukunya A. History of Classical Malay Literature.(1969) tidak membicarakan hal itu. Demikian pula Fang dalam bukunya Sejarah Kesusastraan Melayu Klasik 1 (1991) tidak membahas hikayat itu. Salah satu pakar sastra yang membicarakan hikayat ini adalah Dipodjojo dalam bukunya Kesusatraan Indonesia Klasik pada Zaman Pengaruh Islam I (1981). Namun, dalam buku itu hikayat itu hanya dikemukakan secara garis besar.

Di Musium Pusat Jakarta tersimpan beberapa naskah tentang nabi mengajar Fatimah. Katalogus Koleksi Naskah Melayu Musium Pusat Dep. $P$ dan $K(1972 / 73)$ yang disusun oleh Tim Proyek Inventarisasi dan Dokumentasi Kebudayaan Nasional Direktorat Jenderal Kebudayaan Tahun 1972/73 menyebutkan tiga buah naskah, dengan nama Hikayat Nabi Mengajar Anaknya Fatimah I, II, dan III. Konon di Leiden dan Royal Asiatic Society London juga tersimpan naskah Hikayat Muhammad Mengajar Anaknya Fatimah (Dep. P dan K, 1972/73: 177).

Judul naskah-naskah itu tidak selalu sama. Ada yang bernama Hikayat Nabi Mengajar Anaknya Bibi Fatimah; Hikayat Fatimah Bersuami; Hikayat Fatimah Kawin; Hikayat Bibi Fatimah. Hikayat yang menjadi bahan kajian berasal dari Musium Pusat Jakarta. Bahan ini diterima penulis dalam bentuk fotokopi. Naskah ini terdiri dari tiga belas halaman dengan menggunakan huruf Arab-Melayu tulisan tangan. Tampaknya naskah ini bukan merupakan naskah yang berdiri sendiri. Namun, merupakan bagian dari suatu naskah sebab pada bagian akhir bersambung dengan Hikayat Baginda Ali.

DIKSI Vol.10, No.2, Juli 2003 
Hikayat bernuansa islami ini memberikan tuntunan bagaimana mewujudkan surga dalam rumah tangga. Dalam hikayat ini peranan wanita sangat menonjol, sehingga batangkali dapat menjadi bahan renungan bagi kaum feminis yang ingin memosisikan wanita dalam peran yang sangat mulia.

\section{B.HRMF dan Feminisme}

\section{Perkembangan Feminisme}

Feminisme sebagai suatu gerakan yang ingin memperjuangan hak-hak kaum wanita sejajar dengan kaum pria telah mendunia. Oleh karena itu, pendefinisiannya menjadi sangat beragam. Akibatnya, feminisme diungkapkan secara berbeda-beda di berbagai bagian dunia. Demikian pula bentuk dan target yang hendak dicapai oleh perjuangan mereka.

Feminis liberal mendasarkan perjuangannya pada pemikiran bahwa semua orang diciptakan dengan hak-hak yang sama dan setiap orang harus mempunyai kesempatan yang sama untuk memajukan dirinya. Dalam pandangannya wanita belum mendapatkan hak yang sama dengan laki-laki, terutama untuk memajukan dirinya. Oleh karena itu, gerakan ini berusaha menyadarkan kaum wanita untuk menyadari posisinya dan kemudian menuntut hak-haknya. Ada dua macam cara yang digunakan untuk mencapai tujuannya. Pertama, melakukan pendekatan psikologis dengan membangkitkan kesadaran individu, antara lain melalui diskusi yang membahas peranan wanita yang berada dalam masyarakat yang dikuasai kaum pria. Kedua, menuntut pembaharuan hukum yang selama ini tidak menguntungkan kaum wanita. Perjuangan mereka di Amerika telah membuahkan hasil dengan diberlakukannya no fault divorse, yaitu istri diperbolehkan menceraikan suami tanpa melihat siapa yang bersalah. Demikian juga dengan diberlakukannya marriage contract, yaitu setiap pasangan yang menikah boleh membuat term kontraknya sendiri, tanpa mengikuti 
hukum perkawinan yang berlaku. (Wa Islama, 32/XII, 19 April 2002:2)

Feminisme Marxis yang dikembangkan oleh Engels dengan mengacu pada teori materialisme Karl Mark berpendapat bahwa suami adalah cerminan dari kaum borjuis dan istri sebagai kaum proletar yang tertindas. Untuk mengatasi hal ini Engels (Wa Islama, 32/XII, 19 April 2002:2) mengusulkan agar kaum wanita masuk ke sektor publik sebagaimana dimasuki kaum laki-laki, sehingga mereka mampu menghasilkan barang dan uang. Konsep pekerjaan domestik yang selama ini dilakukan wanita dihilangkan, sehingga wanita tidak perlu lagi mengurus rumah tangga dan anaknya. Sebagai gantinya diciptakan keluarga kolektif yang mengerjakan tugas domestik secara bersamasama, termasuk mengasuh dan mendidik anak. Dengan metode ini diharapkan terwujud kesamaan kedudukan antara wanita dan pria.

Feminis radikal beranggapan bahwa faktor utama yang menjadi penyebab pembagian kerja berdasarkan jenis kelamin adalah sistem patriakhal., yaitu pria mengendalikan wanita dengan kekuasaannya. Teori Finestone (Wa Islama, 32/XII, 19 April 2002:3) menyatakan bahwa kelemahan wanita sebenarnya terletak pada struktur biologisnya. Artinya, wanita harus melahirkan anak, mengasuh anak, menyusui, dan sebagainya. Semua ini merupakan penyebab ketergantungan wanita terhadap pria.

Sementara itu, feminis sosialis yang merupakan sintesis feminis Marxis dan feminis radikal berasumsi bahwa masyarakat kapitalis bukan satu-satunya penyebab keterbelakangan wanita, sebab dalam kenyataannya yang telah bekerja pun mengalami kungkungan sistem patriarkhal. Gerakan feminis sosialis mengharapkan munculnya kesadaran wanita tentang posisi mereka dengan menonjolkan isu-isu bagaimana wanita diperlakukan tidak manusiawi, dikurung dalam sangkar emas. Targetnya adalah munculnya konflik perlawanan kaum wanita untuk menumbangkan sistem patriarkhal.

Perjuangan kaum feminis tampaknya tidak akan membuahkan hasil yang menguntungkan bagi kemanusian, apabila hanya 
mengedepankan tuntutan persamaan hak. Dalam konteks kehidupan rumah tangga, tuntutan terhadap persamaan hak dapat menimbulkan konflik yang kepanjangan dan memuncak, sehingga berakhir pada kehancuran rumah tangga. Sementara itu, dalam banyak hal perceraian mengakibatkan penderitaan lahir dan batin pada semua pihak.

Keadaan seperti itu mulai disadari berbagai pihak sehingga mereka berusaha mengembangkan feminisme yang lebih elegan. Bagaimana sebenarnya menempatkan wanita sesuai dengan kondratnya, tanpa harus merasakan ketertindasan dari kaum pria.

Solusinya, dapat dilihat pada serpihan kisah-kisah lama yang menunjukkan kiprah wanita pada zamannya. Kisah-kisah lama ternyata telah memunculkan realitas dan pemikiran tentang peranan penting kaum wanita dalam kehidupan sehari-hari, baik dalam lingkup makro maupun mikro. Ternyata dalam kisah-kisah lama, kaum wanita telah memperoleh apresiasi yang luar biasa.

Dalam lingkungan makro, berbagai peristiwa penting dalam pentas dunia tidak lepas dari peran wanita. Hal ini dapat dikaji dalam sastra lama yang sarat dengan nilai edukatif. Hikayat Ambiya (Dipodjojo, 1981:40) berkisah tentang pembunuhan pertama kali, manusia atas manusia yang dipicu oleh perebutan wanita antara Qabil dan Habil. Cerita Rakyat Daerah Jawa Barat (Danandjaja, 198475-76) berkisah tentang hubungan diplomatik antara Jawa dengan Cina pada masa lampau yang dijembatani oleh perkawinan silang dengan putri Cina. Cerita Rakyat DIY menceritakan Ki Ageng Mangir yang bertekuk lutut di hadapan Panembahan Senopati akibat kepiawaian spionase wanita, yang diperankan oleh Nyi Pembayun putri Panembahan Senopati.

Sementara itu, dalam lingkup mikro, peranan wanita sangat penting. Dalam kehidupan seorang pria kehadiran perempuan sebagai pendamping sangat diperlukan, sampai-sampai dikatakan bahwa seorang pria belum dianggap sempurna tanpa kehadiran seorang wanita. Mengingat peranannya yang sangat penting maka para suami akan 
banyak kesulitan (kewalahan) apabila ditinggalkan oleh istri. Waljinah "Si Walang Kekek" mengemukakan pemeo (sindiran) lewat tembangnya "Aja ngenyek karo wong wedok, yen ditinggal lunga setengah mati"

Wanita sebagai sosok makhluk yang memiliki peran penting, dapat berbuat apa saja di dunia. Artinya, bila dikehendaki, mereka dapat menciptakan kedamaian. Sebaliknya, mereka juga dapat memicu pertikaian. Hal ini sangat bergantung dari peran yang mereka mainkan, apakah positif atau negatif. Dalam peran positif wanita dapat menciptakan kebahagiaan dan kesejahteraan hidup rumah tangga, masyarakjat, dan negara. Oleh karena itu, tidak mengherankan apabila selama ini banyak pihak yang berusaha mengeksploitasi wanita, baik sebagai pelaku maupun objek, dalam pembangunan masyarakat. Dasa Wisma, PKK, dan Darma Wanita, adalah organisasi-organisasi yang berusaha menggali potensi wanita untuk pembangunan guna mewujudkan masyarakat yang sejahtera. Mereka menjadikan wanita sebagai objek sekaligus pelaku dalam pembangunan.

Dalam kehidupan spiritual, berbagai agama mengakui peran wanita yang tidak kalah penting dengan pria. Agana Islam, misalnya, memandang wanita sebagai sosok yang dapat menciptakan surga. Nabi Muhammad bersabda "Aljannatu tahta aqdaamil ummahaat" 'Surga itu berada di bawah telapak kaki kaum ibu' (Rochman, 1993:144) . Simbolisasi ini menggambarkan kedudukan dan peranan kaum wanita yang sangat strategis untuk mewujudkan kebaikan di berbagai bidang.

\section{Peran Wanita dalam $H R M F$}

$H R M F$ termasuk salah satu khasanah sastra Indonesia lama yang bernilai sex education. Hikayat yang bernuansa islami ini berisi dialog antara Muhammad Rasulullah dengan putrinya yang bernama Fatimah tentang konsep Islam untuk mewujudkan keluarga yang bahagia, yang dalam terminologi agama dikenal dengan sakinah, wa waddah wa rahmah, dan baitii jannatii 'rumahku adalah surgaku' Melalui dialog-dialog itu dapat diketahui bagaimana feminisme dalam 
$H R M F$ diberdayakan untuk memposisikan wanita pada kedudukan yang terhormat dalam rangka mewujudkan surga rumah tangga.

Surga salah satu manifestasi kebahagiaan paling prima. Kitab suci memuat beberapa metafor yang menggambarkan surga sebagai tempat yang penuh dengan kenikmatan, kelezatan, kesejahteraan kedamaian, dan kebahagiaan yang abadi. Di dalamnya terhampar permadani yang indah-indah, tersedia bermacam-macam minuman dan makanan yang lezat, tempat tidur dengan guling yang empuk, ditambah dengan bidadari yang cantik rupawan. "Perumpamaan surga yang dijanjikan kepada orang-orang yang bertakwa di dalamnya ada sungaisungai dari air yang tiada berubah rasa dan baunya, sungai-sungai dari air susu yang tiada berubah rasanya, sungai-sungai dari khamar (arak yang lezat rasanya bagi peminumnya), sungai-sungai dari madu yang disaring; dan mereka memperoleh di dalamnya segala macam buahbuahan dan ampunan dari Tuhan mereka" (Alquran, 47: 15). Dalam suràt dan ayat lain disebutkan, "Dalam surga yang tinggi, tidak kamu dengar di dalamnya perkataan yang tidak berguna. Di dalamnya ada mata air yang mengalir. Di dalamnya ada tahta-tahta yang ditinggikan dan gelas-gelas yang terdapat (di dekatnya), dan bantal-bantal yang tersusun, dan permadani-permadani yang terhampar" (Alquran, 88: 10-16).

Surga yang hakiki sebagai suatu tempat yang sarat dengan kenikmatan, menjadi impian dan harapan setiap orang. Menurut ajaran agama surga yang demikian itu terdapat di alam rohani (gaib), yang dapat diraih melalui hidup dan kematian yang sempurna. Iman dan amal salih yang disempurnakan dengan kematian yang khusnul khatimah. Arifin (1983/84:49) menjelaskan bahwa surga adalah suatu tempat di akhirat yang disediakan oleh Allah swt. untuk hamba-hamba-Nya yang takwa kepada-Nya, dan sebagai balasan kepada mereka atas keimanan dan amal salehnya.

Dalam kehidupan dunia, rumah tangga yang sarat dengan kemewahan, dan kebahagiaan dikonotasikan sebagai surga dunia. Sebaliknya, kehidupan dunia atau keluarga yang serba kekurangan, 
sering terjadi keributan, dikiaskan sebagai neraka dunia

Untuk mewujudkan surga dalam rumah tangga, seseorang dapat berpedoman pada $H R M F$. Surga yang dimaksudkan oleh $H R M F$ tidak semata-mata bertumpu pada kecukupan materi, melainkan lebih ditekankan pada kebahagiaan batin. Hal ini bukan berarti fisik dan materi tidak diperlukan.

$H R M F$ merupakan salah satu warisan khasanah sastra lama Indonesia yang tersebar bersamaan dengan penyiaran agama Islam. Misi utama hikayat itu adalah memberikan pengajaran bagaimana seharusnya seorang wanita mewujudkan kebahagiaan dalam rumah tangga. Pengajaran tersebut menyiratkan penerapan feminisme dalam rumah tangga. Dengan kata lain, bagaimana seharusnya seorang wanita sebagai istri berperan dalam rumah tangga.

Hikayat ini lebih menekankan pada pesan moral yang ingin di sampaikan. Tokoh yang ditampilkan, yaitu Rasulullah dan Fatimah adalah tokoh yang amat dikenal di kalangan umat Islam. Muhammad Rasulullah dalam agama Islam adalah seorang nabi dan rasul terakhir yang diangkat oleh Allah untuk menyampaikan agama Islam ke seluruh dunia. Di katakan dalam Alquran "Dan tidaklah Kami mengutus kamu, melainkan untuk (menjadi) rahmat bagi semesta alam " (Alquran, $21: 107)$.

Dalam hikayat ini nabi betul-betul dijadikan tokoh yang utama. Disebutkan bahwa " Rasulullah itu penghulu sekalian nabi yang sakti dua laksa tiga ribu tiga ratus $(H R M F: 1)$. Penokohan ini dimaksudkan untuk meningkatkan kewibawaan nabi sebagai seorang tokoh yang memberikan pengajaran. Barangkali penokohan ini juga dimaksudkan untuk meyakinkan pembaca akan kebenaran isi hikayat ini.

Sementara itu, Fatimah adalah putri Nabi Muhammad saw. Dia adalah satu-satunya putri nabi yang memiliki keturunan dari perkawinannya dengan Ali bin Abi Thalib, saudara sepupu Nabi Muhammad saw. Perkawinan yang masih bertalian kerabat ini melahirkan dua orang putra yaitu Hasan dan Husen, yang peristiwa 
kematiannya sering dirayakan dengan berbagai tradisi oleh umat Islam yang berpaham Syiah.

Dipodjojo (1981:19) mengatakan bahwa aliran Syiah memegang pendirian yang kokoh bahwa yang berhak sebagai pewaris Nur Muhammad ialah Ali bin Abi Thalib dan keturunannya dari perkawinannya dengan Fatimah, anak perempuan Nabi Muhammad. Dalam kedudukannya sebagai tokoh dalam hikayat itu, Fatimah digambarkan sbb: "... penghulu sekalian perempuan dalam dunia ini" (HRMF:1).

Pada awal hikayat ini tertulis "Bismilahirahmanirrahim" (HRMF:1). Pembuka wacana dengan bacaan basmallah merupakan kelaziman dalam naskah-naskah yang bernafaskan Islam. Kebiasaan ini merupakan perwujudan ajaran Islam yang menganjurkan umatnya untuk memulai sesuatu dengan bacaan basmalah. Barangkali kebiasaan seperti itu meniru surat-surat yang terdapat dalam Alquran yang sebagian besar dimulai dengan basmallah.

Pada bagian akhir hikayat terdapat penunjuk titimangsa penulisan, yaitu " ... tersurat Jumadi ' l-akhir pada hari Selasa pada jam pukul dua" (HRMF:13). Sangat disayangkan bahwa kolofon itu tidak menyebutkan tahun penulisan sehingga tidak dapat diperkirakan usia naskah tersebut. Meskipun demikian, kolofon itu mengindikasikan bahwa penulis memiliki kepedulian terhadap waktu, baik bulan, hari maupun jam.

Judul naskah ini menggunakan kata hikayat, sebagaimana disebutkan ".. wa bihi nastangii nu ini hikayat segala Rasulullah shalla llahu 'alaihi wa sallam mengajar Fatimah a zzahra ... " (HRMF:1). Namun, istilah hikayat ini tidak seperti hikayat yang dikenal orang. Di dalam hikayat itu tidak tergambar struktur atau alur cerita seperti hikayat-hikayat yang lain. Demikian pula latar cerita tidak tergambarkan.

Hikayat ini tidak memaparkan suatu kisah tentang kehidupan para tokoh dan pengalamannya, tetapi menyajikan pengajaran yang 


\section{3}

disampaikan dalam bentuk dialog antarpara tokoh. Pemaparan semacam itu memang tidak lazim dalam naskah-naskah lama. Namun, bukan berarti tidak ada yang lain. Kitab Seribu Masalah, misalnya menggunakan paparan dalam bentuk tanya jawab. Model pemaparan seperti itu barangkali dapat dicari rujukannya pada hadis-hadis nabi, yang banyak menampilkan dialog.

Dialog antara nabi dan putrinya tergambar dalam kalimat berikut: Maka sabda Rasulullah, "Hai anakku Fatimah, aku ajar engkau kepada perintah dan tertib hukum perempuan kepada suaminya" ( $H R M F: 1)$. Selanjutnya, dijawab oleh putrinya: "Ya ayahanda, hamba ini belum tahu perintah orang bersuami karena hamba dengar kabar orang bersuami itu banyak dosanya "(HRMF:1). Pada jawaban Fatimah itu sebenarnya tersirat pertanyaan benarkah bahwa orang bersuami itu banyak dosanya. Pertanyaan ini kemudian dijawab oleh Rasulullah dengan pengajaran tentang kebaktian seorang istri terhadap suami. Selanjutnya, akhir jawaban Rasulullah menyakinkan bahwa istri yang berbakti pada suami akan mendapatkan pahala. Dikatakannya; "Hai anakku Fatimah, maka demikianlah dikerjakan oleh segala perempuan kepada suaminya dibalaskan Allah ta'ala akan dia pahala yang amat besar terlebih daripada satu Bukit Uhud namanya dan diampuni dosanya" (HRMF:7). Penegasan ini menepis keragu-raguan sekaligus memberikan motivasi kepada seorang untuk bersuami.

Tiga potongan ayat Alquran dikutip dalam hikayat ini, yaitu pada halaman 6, 7, dan 11, masing-masing surat $A n$ nisa (4:3), surat Albaqarah (2:223), dan surat $A l$ a'raf (7:179). Ketiga ayat itu, masingmasing berisi tentang perintah nikah, perintah menggauli istri, dan penghuni neraka.

Secara garis besar $H R M F$ memberikan pengajaran tentang dua hal, yaitu (1) kebaktian istri terhadap suami, (2) perbuatan jahat istri terhadap suami. Di samping itu, terdapat ketentuan tentang (1) perempuan yang baik untuk dinikahi, dan (2) jumlah istri yang diperbolehkan. Selain itu, $H R M F$ juga menyinggung pahala bagi istri 
yang setia dan siksa bagi istri yang durhaka.

Sepuluh kebajikan yang diingatkan kepada perempuan, yaitu (1) memenuhi kehendak suaminya kepada barang suatu kebajikan; (2) segera menyahuti panggilan suaminya dengan muka manis; (3) membubuh minyak pada rambut suaminya atau menggosok tubuh suaminya dengan bau-bauan; (4) membuat makanan untuk menjamu orang atas perintah suaminya; (5) menghias suaminya pergi sembahyang Jumat atau hari raya; (6) minta izin suaminya untuk sembahyang, puasa, atau memberi makan orang yang puasa dan orang yang lapar; (7) segera memenuhi panggilan suaminya kepada tempat tidurnya; (8) menyucurkan air mandi junub suaminya; (9) mengasihi mertuanya, guru suaminya, anak yatim, saudara suaminya, (10) tiada mau berbuat zina meski dibujuk oleh laki-laki lain.

Sepuluh kebaktian ini tidak dimaksudkan untuk memposisikan istri sebagai pelayan, tetapi menempatkan istri sebagai pilar kebahagiaan rumah tangga. Sudah barang tentu, sepuluh kebaktian itu dalam praktik sehari-hari, tidak dimaknai secara harfiah, melainkan secara kontekstual. Membubuhi minyak pada rambut suaminya atau menggosok suaminya dengan bau-bauan, misalnya, dapat dimaknai adanya perhatian sang istri terhadap suami dalam berbusana.

Apabila dicermati, sepuluh kebaktian itu merupakan dasar-dasar untuk melakukan pengabdian yang prima terhadap suami. Di dalamnya terdapat pengajaran yang bersifat fisik, material, psikologis, emosi, sosiologis, etik dan estetis. Kebaktian yang sempurna akan memberikan kepuasan lahir dan batin bagi seorang suami, sehingga tidak alasan sedikit pun untuk melakukan hal-hal yang negatif terhadap sang istri. Oleh karenanya, suami akan mengimbangi dengan memenuhi kewajibannya kepada istri.

Dalam hal ini kewajiban utama suami adalah memberikan nafkah lahir dan batin. Kewajiban ini secara operasional dapat dijabarkan ke dalam enam macam, yaitu (1) mencukupi belanja rumah tangga, (2) menyediakan pakaian dan perumahan, (3) sopan, bermuka 
manis, dan memberikan kasih sayang pada istri, (4) memberikan perhatian penuh pada istri, (5) hormat kepada orang tua dan kerabat istri, (6) menghias diri, berpakaian bersih dan rapi untuk istri (Amir, 1977:70).

Apabila istri dan suami melaksanakan kewajibannya masingmasing secara tidak langsung mereka akan mendapatkan haknya. Dengan demikian, sebuah keluarga yang harmonis akan terwujud. Surga dunia pun dapat dinikmati. Sementara itu, surga yang hakiki sudah terbayang di depan pelupuk mata hatinya.

Selanjutnya, sebagai langkah antisipatif terhadap berbagai hal yang bersifat negatif, dikemukakan sepuluh perbuatan yang amat berdosa. Kesepuluh perbuatan itu adalah (1) berzina di belakang suaminya; (2) membunuh anak dalam perutnya; (3) memaki suaminya; (4) mengumpat suaminya atau lambat memenuhi panggilan suaminya ke tempat tidur; (5) mencuri harta suaminya; (6) menjeling suaminya dengan muka masam karena kasih pada laki-laki lain; (7) marah pada apa yang diminta oleh suaminya; (8) tiada mau menegur jamu suaminya atau lambat memberi sesuatu; (9) pergi ke mana-mana tanpa izin suaminya; (10) tidak diturut perintah suami pada hal-hal yang diwajibkan Allah.

Untuk memberikan tekanan pada kesepuluh peringatan ini, dikemukakan satu contoh tentang balasan yang akan dirasakan oleh istri yang berselingkuh. Dinyatakannya, "Maka segala perempuan yang zina di belakang lakinya itu dimasukkan Allah ta'ala ke dalam parjinya kala yang terlebih panas daripada api neraka, akan menjepit parjinya, keluar darah dan nanah daripada pihaknya terlebih busuk baunya di dalam mereka itu, maka diludahilah oleh segala isi neraka itu mukanya, demikianlah dosa perempuan yang melalui hukum Allah" (HRMF:9). Deskripsi tentang perselingkuhan ini jauh lebih vulgar daripada yang dinyatakan dalam Alquran, yang mengingatkan "wala taqrobu zzina innahu kaana faakhisatan wa saa a sabiilan" Dan janganlah kamu mendekati zina, sesungguhnya zina itu adalah perbuatan yang keji, dan suatu jalan yang buruk (Alquran, 17:32).

Masalah lain yang erat hubungannya dengan pembinaan rumah 
tangga, ialah (1) istri yang pantas dinikahi, dan (2) jumlah istri. Disebutkan tentang perempuan yang baik untuk dinikahi "maka nikah oleh kamu perempuan yang baik pada hati kamu, yang bangsa, dan yang baik budinya, yang sah kepada sanak saudara yang banyak, dan perempuan yang banyak anaknya, maka lihat kepada ibu bapanya, dan yang kaya, dan baik tubuhnya" (HRMF:6). Apa yang dikemukakan itu sejalan dengan hadis nabi yang mengemukakan kriteria calon istri. Dikatakan oleh Rasulullah "Dikawini perempuan itu dalam empat perkara, yaitu karena hartanya, keturunannya, kecantikannya, dan agamanya, maka pilihlah karena agamanya maka akan selamatlah engkau" (Bahreisy, 1980:312).

Tentang jumlah istri yang halal dinikahi disebutkan "..maka nikah oleh kamu perempuan itu dua atau tiga orang atau empat oranglah, maka tiada dibolehkan engkau nikah dengan lima orang perempuan yang dhahir hukumnya melainkan engkau talak salah satu daripadanya " (HRMF:6). Selanjutnya, ketentuan ini diperkuat dengan kutipan ayat Alquran "Fankiuhuu maa thabalakum mina nnisaa i mastnaa wa stulaatsa wa ruba 'a fa in hiftum anla ta' dilu fa waa hidatan maa malakat aimanukum" (HRMF: 6). Arti dari ayat ini adalah nikahilah wanita yang kausenangi dua, tiga, atau empat. Kemudian jika kamu takut tidak akan dapat berlaku adil, maka kawinilah seorang saja atau budak-budak yang kamu miliki (Alquran, 4:3).

\section{C.Penutup}

Konsep feminisme dalam $H R M F$ menekankan peran wanita (istri) dalam menciptakan kebagiaan rumah tangga. Hal ini sejalan dengan sabda nabi yang mengatakan bahwa surga itu berada di bawah telapak kaki ibu. Dalam penafsiran yang agak bebas, wanita dapat menciptakan surga, baik dalam pengertian yang sebenarnya maupun dalam pengertian yang lebih konkret, yaitu surga dunia.

Salah satu upaya untuk menciptakan surga dalam rumah tangga 
adalah dengan mempraktikkan sepuluh kebaktian istri terhadap suami. Kebaktian yang prima terhadap suami akan menjadikan suami betah (krasan) di rumah dan selalu merindukan rumah. Apabila hal itu terwujud, maka kemungkinan terjadinya perselingkuhan oleh suami akibat kurang mendapatkan perhatian dari istri akan terhindarkan. Dengan demikian, wanita telah menduduki peran yang mulia yaitu mewujudkan surga.

Apabila hal ini dapat diwujudkan dalam setiap rumah tangga, maka rumah tangga akan dirasakan seperti halnya surga yang penuh dengan kenikmatan, kedamaian, kesejahteran, dan kebahagiaan.

Rumahku adalah surgaku "Baitiijannatii", semoga.

\section{Daftar Pustaka}

Amir, W. 1977. Pendidikan Agama. Yogyakarta: Kota Kembang.

Arifin, M. 1984/85. Pendidikan Agama Islam. Jakarta: Depag.

Bahreisy, H. 1980. Himpunan Hadits Pilihan Hadits Shahih Bukhari. Surabaya: Al Ikhlas.

Bahreisy, S. 1999. Sejarah Hidup Nabi-nabi (Qashashul Anbiyaa'). Surabaya: Bina Ilmu.

Danandjaja, J. 1984. Folklor Indonesia: Ilmu Gosip, Dongeng, dan lain-lain. . Jakarta: Grafiti.

Depag. 1989. Al Quran dan Terjemahannya. Jakarta: Depag.

Dep. P dan K, 1972/73. Katalogus Koleksi Naskah Melayu Musium 
Pusat Dep. P dan K ( M. Amir Sutaarga, dkk) . Jakarta: Proyek Inventarisasi dan Dokumentasi Kebudayaan Nasional, Direktorat Jenderal Kebudayaan Dep. P dan K.

Dipodjojo, A.S. 1981. Kesusatraan Indonesia Lama pada Zaman Pengaruh Islam I. Yogyakarta: Lukman.

Fang, L. Y. 1991. Sejarah Kesusasteraan Melayu Klasik I. Jakarta: Erlangga.

"Mengenal Feminisme". 2002. Wa Islama: Buletin Dakwah. Edisi 32/XII. Yogyakarta: Yayasan Kajasha.

Rochman, F. 1993. Ayat-ayat Al Quran \& Al Hadits untuk Dasar Pedoman Berpidato. Surabaya: Apollo.

Sutrisno, S. 1981. Relevansi Studi Filologi. Yogyakarta: Penerbit Liberty.

Winstedt, S. R. 1969. A History of Classical Malay Literature. Kuala Lumpur Singapura: Oxford University Press 